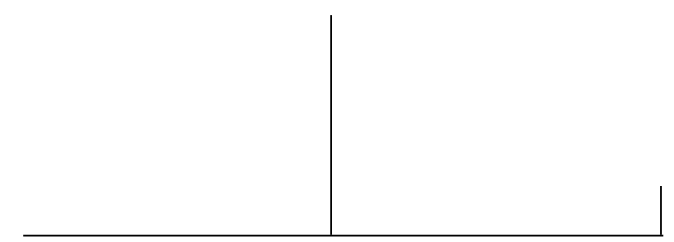

Rev. Latinoam. Psicopat. Fund., São Paulo, v. 13, n. 3, p. 425-440, setembro 2010

\title{
Surgical treatment of obesity: some considerations on the transformations of the eating impulse*
}

\author{
Ronis Magdaleno Júnior \\ Elinton Adami Chaim \\ Egberto Ribeiro Turato
}

\begin{abstract}
This study aims at understanding the alteration of the eating impulse arising after bariatric surgery. Hunger is transformed after surgery, with satiety being quickly achieved, but not the sensation of satiation. There is an evident misunderstanding between hunger as non-satiety and as dissatisfaction, with anguish emerging as the resulting affect, which surgery does not correct. In-depth psychological treatment is crucial as the surgery creates new emotional demands for the patient.
\end{abstract}

Key words: Bariatric surgery, obesity, psychoanalysis, qualitative method

* This manuscript refers to an original piece of research conducted in the surgical service of the General Hospital of Unicamp, validated by peer reviewers from the Laboratory of Clinical-Qualitative Research, Unicamp, Campinas, Brazil, based on doctoral thesis of Ronis Magdaleno Júnior entitled "Life experiences of women submitted to bariatric surgery in General Hospital of Unicamp: a clinical-qualitative study". Advisor: Prof. Dr. Egberto Ribeiro Turato. 


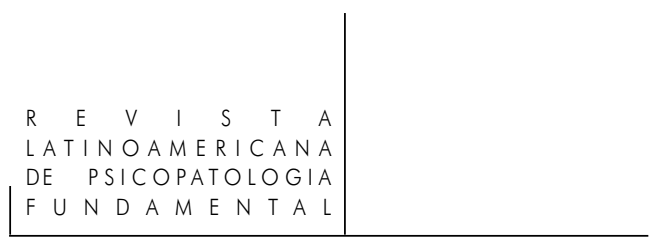

Obesity has currently reached epidemic proportions throughout the world (World Health Organization, 2008). The poor results of the therapeutic strategies that use drugs, diet and behavior modification in severely obese patient (Segal and Fandiño, 2002; Santry, 2005; Buchwald, 2005; Weintraub, 2008), have led to a significant increase in the number of bariatric surgeries over the last few decades (American Society for Bariatric Surgery, 2007).

Bariatric surgery is a procedure which proposes a quick and radical solution to a complex problem of morbid obesity and its clinical, social and psychological complications. However, interfering in the delicate psychological balance in which obesity is situated provokes postoperative experiences in patients which they are unprepared to deal with (Magdaleno Jr., 2009a; 2009b).

The challenges presented in the medium and long-term are: how to adopt and maintain new eating habits (Delin, 1995; Bocchieri, 2002) and how to undo the overlap that exists between anguish, helplessness and the impulse to ingest food (Tustin, 1990; Oliveira \& Palauro, 2007). It is in this sense that Delin et al. (1995) affirm that surgery does not solve the problem of the patients being incapable of distinguishing between physiological and psychical hunger.

From the psychodynamic view point, morbid obesity is the phenomenological expression of a particular psychic structure. Freud $(1905,1914)$ described the phases of psycho-sexual development of the human being, postulating an initial auto-erotic phase, prior to narcissism and thus before the oral phase, in which there is still no Ego. In this initial phase, the psyche reacts anarchically to the drives and stimuli received from outside. It is in this context that the most primitive symptoms are structured to be expressed later by fusional and addictive attitudes. An imbalance in the eating function, which is the characteristic of morbid obesity, may be the phenomenon observed that reveals an imbalance in relation to the subject and his environment. The incapacity to create a symbolic referent to provide a destination for the violent pressure of the primitive drives (Botella, 2007; Barros, 2007) leaves the way for the immediate, corporal discharge of the impulses open, which is at the base of the psychic structure of obesity.

Rev. Latinoam. Psicopat. Fund., São Paulo, v. 13, n. 3, p. 425-440, setembro 2010 
Due to this symbolic deficiency, the morbidly obese are compelled to use rational and objective resources in an attempt to control the drive-impulses. The eating behavior of these patients arises from this tension between the desire for food and the available regulating mechanisms, and is characterized by a rigid control of their food intake, alternating uninhibited and compulsive eating with bulimic attacks and the habit of eating exaggeratedly, not compulsively, highly calorific drinks and food (van Hout, 2004).

Twenty to $50 \%$ of the patients operated are unable to achieve the desired weight loss or present a weight increase a few years after the surgery (Benotti, 1995; Magro et al., 2008). These statistics reinforce the need to investigate factors associated with these therapeutic failures. There is evidence that the presence of Binge Eating Disorder (BED) is related to lower weight loss and to regaining weight in the post-operative period, constituting a strong prediction for failure in surgical results (Hsu, 1996, 1997; Dymek, 2001; Kalarchian, 2002). Much less frequent than BED are cases of Anorexia Nervosa which appear after bariatric surgery (Bonne, 1996; Atchinson, 1998; Cordás, 2004), pointing to transformations in the eating impulse that go beyond the simple restriction of the volumetric capacity of the stomach and the absorption of nutrients.

An important question related to obesity and which influences the postoperative evolution is the psychological structure that sustains the obesity, with those having less symbolic elements in their psychological structure showing greater possibilities of regaining weight and of post-operative complications (Magdaleno Jr., 2009).

The aims of the present study are: to endeavor to understand the transformations that take place in the eating habits of women who have undergone bariatric surgery, how they re-adapt to their new anatomical condition after having their eating capacity restricted by the surgery and how they try to reorganize themselves emotionally.

\section{Subjects and methods}

This study had a clinical-qualitative design, a particularization of the qualitative method applied to a specific health setting that permits us to understand the life experiences and the process of the suffering of the individuals in relation to a determined problem in the health-illness process. Thus, this method adopts a humanistic model, seeking to interpret scientifically the meanings that individuals' life experiences acquire (Turato, 2008). Qualitative researchers study their subjects in their natural settings, in an attempt to interpret phenomena in 
terms of the meanings that people attribute to them (Denzin \& Lincoln, 2006; Morse \& Field, 1995). The data collection instrument was the semidirected interview with open-ended questions (Turato, 2008) applied to an intentional sample. In other words, one which is made up of a small number of people, chosen deliberately in function of the importance they have in relation to the given theme and considered bearers of representation (Turato, 2008; Denzin \& Lincoln, 2005; Fontanella et al., 2006). This approach had the aim of ensuring that the matter was discussed in depth with the interviewees. This produces data with the aim of reformulating, deflecting, complementing and/or clarifying initial hypotheses (Merton, 1967). The study sample consisted of seven women operated in the surgical service of the General Hospital of University of Campinas (Unicamp), a tertiary public university hospital, located in the city of Campinas, state of São Paulo, Brazil, in a period of one year and six months to three years. This interval was previously established and excludes the first post operative 12 months, during which time strong elements of denial and a disproportional increase of self esteem occur.

Table 1

Sample characterization by individual: gender, age, marital status and time since surgery

\begin{tabular}{|l|l|l|l|l|}
\hline Name & Age & Sex & Time Since Surgery & Civil status \\
\hline \hline P1 & 49 & $\mathrm{~F}$ & 3 years & Married \\
\hline P2 & 33 & $\mathrm{~F}$ & 2 years and 2 months & Married \\
\hline P3 & 37 & $\mathrm{~F}$ & 1 year and 6 months & Married \\
\hline P4 & 39 & $\mathrm{~F}$ & 1 year and 11 months & Single \\
\hline P5 & 45 & $\mathrm{~F}$ & 2 years and 11 months & Separated \\
\hline P6 & 28 & $\mathrm{~F}$ & 1 year and 6 months & Married \\
\hline P7 & 49 & $\mathrm{~F}$ & 1 year and 11 months & Widow \\
\hline
\end{tabular}

The sample was closed at this number by utilizing the saturation criterion (Glaser \& Strauss, 1999; Fontanella et al., 2008). The interviews were taped with the permission of the patients. The transcriptions from the interviews formed the corpus for the study and were subjected to analysis. After applying the

Rev. Latinoam. Psicopat. Fund., São Paulo, v. 13, n. 3, p. 425-440, setembro 2010 


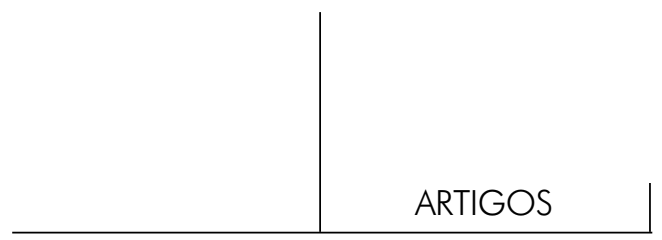

categorization strategy (Turato, 2008; Minayo, 2007), the categories for this study were selected.

From the material collected, the researcher, a medical doctor and trained psycho-analyst, made use of suspended attention vis-à-vis the patients' speech, a fundamental methodological resource in psychoanalysis, and the emotions awakened by it (Hermann, 1989; Magdaleno Jr., 2005). The phenomena thus identified can then be interpreted so as to generate concepts capable of generalization in order to understand further settings. The emerging categories were validated by peer-reviewers from the Laboratory of Clinical-Qualitative Research, Unicamp.

The research project was approved by the Ethical Research Committee of the Faculty of Medical Sciences of Unicamp.

\section{Discussion}

\section{a. Transformations of hunger after bariatric surgery}

Francis Tustin (1990) postulated that many adult patients, even those who present basically neurotic structures and therefore have an adequate social functioning, can present psychic areas that function using defenses as primitive as those used by autistic children, as a way of protecting themselves from primitive anguish. Oliveira \& Palauro (2007) propose that these autistic defenses, frequently found in cases of alcoholism, drug addiction and bulimia, are present in the base of the psychic structure of morbid obesity.

Therefore, for these individuals, hunger would be perceived as a somatic urgency, expressed by the body through imprecise sensations linked to feelings of emptiness, pain and anguish, that are, as we have seen, at the root of the process of obesity.

We observe how what was described as hunger before the surgery starts to be experienced in a different way, as an emptiness, a pain, a weakness, that are possibly attempts to describe sensations close to the primitive experience of helplessness and lack of psychic representation of the body.

“..., I only remember to eat something when my stomach hurts, when I begin to feel an emptiness and it starts to hurt, then I know..."

The complexity that these patients experience and the meanings they give to the sensation of hunger leads us to believe that the volumetric restriction of the stomach unleashes a complex psychological chain of events that are still far from being understood. 
"It's like a cramp that starts in the stomach, I don't know if I can call it cramp, but it begins to hurt... I don't know how to explain this pain I feel, but I know that if I eat something it will pass. I don't really know whether this pain is hunger, you see?"

The way in which each patient experiences what she feels to be hunger, before the surgery, emerges quite differently after the surgery, which leads us to believe that the hunger of obese patients has a strong emotional element that, when the stomach had a large volumetric capacity, could be fully expressed.

We may surmise that what was described as hunger prior to the surgery was a complex of physical sensations, sensations of emptiness and helplessness and, above all, anguish arising from this sensation of lack of something they cannot define.

"... it's that before it seemed to be anxiety and now I have a pain..."

After initial success, it frequently occurs that some patients go back to eating greater quantities of food, be it due to the dilatation of the stomach or because they have developed a phenomenon called grazing (Glimsky, 2001).

"I can't take a plate of food and eat... not any more...but I keep nibbling, nibbling, nibbling."

It is evident that the volumetric reduction of the stomach, while hindering the attempt to appease the anguish through the ingestion of food, exposes even more the impossibility of symbolization of the somatic sensation of hunger in the mind.

If no psychological and nutritional support is offered to these women, in the medium and long term, they begin to develop new eating habits, that by-pass the physical barrier imposed by the surgery, putting at risk all the effort spent in the struggle against obesity, as the only possibility to satisfy the somatic demand that does not find symbolic psychic mediation.

“... I know I'm not eating right. I have no desire to eat food (...), if I could do without, but if I pass in front of the jar of cookies, of honey cake, I go and get one, you see?"

We observe that the compulsive eating impulse is still present in these patients after the operation, with the difference that the attitude to seek food in exaggerated quantities diminishes, due to the anatomical limitation and the fear of feeling sick after eating.

"... Look, there are days when I pass in front of the hot dog stand ... That smell appears and I really feel like eating a hot dog but I'm afraid...” 


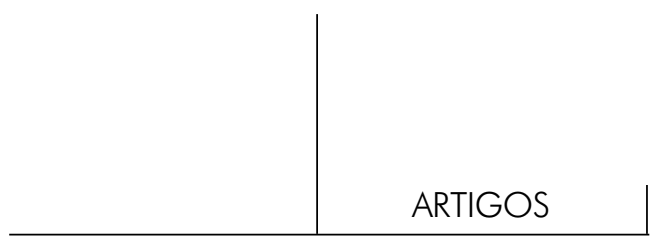

b. Hunger as a non-symbolizable element in morbid obesity

The cohesive identity of the child's body image is founded on the initial experiences, in the sensorial and motor areas, experienced in the fusional relation with the mother. It is a normal symbiotic phase in which the Self is formed based on the mother's image (Mahler, 1967).

Winnicott (1967) called this moment of development the mirror role, in which the child can recognize itself in the mother's face and, from that, begin the process of forming his/her identity. Failures in these initial moments in the formation of the Self force the baby to defend itself, structuring deformed areas in the psyche or representational holes in the mind, which renders it incapable of dealing with instinctual pressure coming from the body.

It is the mother who, as she cares for the baby, looking after its needs and sheltering it in its anguish, helps it to feel that its amorphous body matter can acquire form and contour, based on the containment she offers (Tustin, 1975). Thus, the mother provides a progressive differentiation of the soma of the child towards the formation of a psyche, when she intermediates between the intense instinctual demands coming from within and the demands of the external world. Then, the psyche is that which differentiates itself from the soma, based on the relation with the environment (Winnicott, 1949). Should there be a deficiency in this maturing process, parts of the soma do not become psyche and continue to function in a primitive manner, without an organizing intermediation, subjected to the primary process (Freud, 1911) and to the immediate discharge of tension, expressed by the phenomenon of addiction and is the basis of the psychosomatic illness.

When this initial process does not occur in a satisfactory manner, and the food is offered to the baby in a brutal way without being encompassed in the experience of holding given by the mother, the capacity of the baby to symbolize, to dream and to create a world of fantasy is hindered. The child remains imprisoned in a formless world, lacking in meaning and consequently a world of body sensations (Oliveira \& Palauro, 2007).

Bion (1970) describes a proto-mental configuration in which the physical and the psychic remain in an indifferent state, where the mental is still incipient. This configuration constitutes the matrix from which arise emotional states typical of the Basic Presupposition of Group and psychosomatic illness. This matrix creates registers that remain as archeological tracks of primitive phases of the development. These proto-emotions remain raw, not psychically processed, and cannot be said to be unconscious, since they did not reach this psychological level, being registers lacking psychic inscription (Franco Filho, 2008). At this level of operation, the emotional reactions do not differentiate from the physical reactions, serving more as a discharge than as base for the constructions of representations, symbols and fantasies. 
Meltzer (1990), when speaking about the proto-mental functioning, which he also calls soma-psychotic phenomena, postulates that at this primitive level of mental process a split occurs, and this split part remains separated from the thinking structures of the personality that evolve together with language, having strong influence over the character due to the excessive anxiety that emerges from it.

We may understand the non-symbolized as proto-mental elements occurring at the edges of the mind and endowed with great energy, which pushes to be evacuated through action or somatically. These registers, when not psychically represented, can neither be repressed nor elaborated, and are experienced as present, pressing towards discharge, and revealed by the compulsive repetition of acts (Levy, 2003).

For Botella and Botella (2007), in the initial phases of the process of the creation of a mind, psychic work is required until the formation of mental representations and symbols are achieved. In the event that this process does not occur due to the incapacity of making an emotional state psychic, areas of nonrepresentation will remain and generate a situation of psychic helplessness and emptiness, with implosive effects, that force the individual to "throw into the psyche" substitutes for the missing representation (Botella, 2002, p. 27). The nonrepresentation is experienced as unbearable, leading to the immediate need of defensive mechanisms that enable the fulfillment of the representational emptiness, albeit hallucinatory.

Having these areas of symbolic deficiency, these individuals would not have at their disposal the symbols with their representative and expressive functions. The loss of the ability to represent and express by symbols brings serious mental consequences, since it is by means of the process of construction of symbols that a great part of the process of psychic elaboration occurs.

Metaphorically, the digestion of the emotions would be mediated by the construction of symbols, and through this process of transformation and creation of new symbols, the capacity of thinking about emotional experiences and about relations with the world are enhanced (Barros, 2007).

The inability to create symbols from the non-representation of the emotion, limits the capacity of the morbidly obese to deal with the impact of the drive demand, leaving only the direct path of the repetition of the immediate discharge through the ingestion of food.

"... I have a hole in my head that is bigger than my stomach."

Hunger for the morbidly obese, is an area of representational emptiness, discharging the eating impulse into paths unmeasured by symbolism and, therefore, out of the subject's control. 


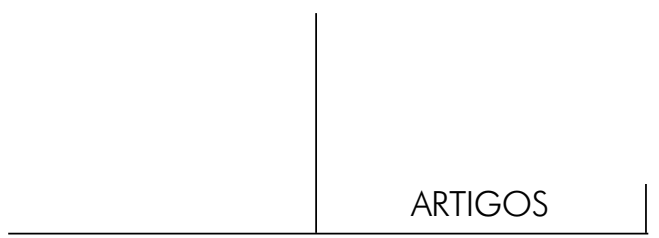

We observe the great difficulty these patients have to control their eating impulse and even to describe what they feel, above all when they try to define their physical experiences after surgery. When they attempt to talk about hunger and consequently, obesity, they end up with an imprecise, marginal description, with elements that tend to by-pass the problem, unable to determine which are the subjective aspects that sustain the symptom. They get lost in interminable explanations, motives and previous vain attempts, all with a view to "combat" obesity.

"Because all this food I eat...my organism, which I operated, had almost stopped, so it doesn't have any calories, it doesn't ingest calories. My organism accumulates all the calories, all the fat, so I need to eat three times less so as not to accumulate so much fat, you see?"

We can observe how the attempt to find an explanation for the problem of hunger tends to lack sense, with reasoning confined to topics that neither develop nor provide a creative solution. In the end, what one observes is a discourse that borders on superficiality, repetition and sterility, rather inefficient for the psychic elaboration of anguish.

One important aspect raised by Hsu et al. (1998) are the alterations relating to satiation and satiety of the patients, and how they are altered in a different way after the surgery. They observe that, in those patients who went back to eating great quantities of food, continually and in smaller portions, satiety is altered by the surgery, whereas satiation is not. These patients learn over time that the frequent ingestion of small quantities of soft food or liquids provides them with a sensation of satisfaction, thus avoiding the discomfort of fullness or dumping (Hsu et al., 1996; 1997).

“... sometimes I have the sensation that I am hungry... that I feel like (eating something), but I begin to eat and soon get full ... so I don't know if the hunger is in my head or not..."

It is important to understand that what the patient calls hunger postoperatively, for there is evidently a confusion between hunger in the sense of nonsatiety and hunger as dissatisfaction. Anxiety appears to be the affective representation of the feeling of dissatisfaction that these patients present.

“... if I'm idle, then it seems that I feel like eating. It's anxiety..."

Based on these findings, we believe that the regulatory mechanisms linked to satiety are directly related to the capacity for gastric complacency, thus being anatomical, whereas the regulation of satiation is carried out by mechanisms of 
another order, possibly metabolic and psychological. It is evident in the operated patients' discourse that satiety is reached quickly whereas satiation is not achieved at the same pace.

"What was operated was the stomach, the head is the same, right... When I was weighing one hundred and thirty kilos, I could serve myself one, two ladles of rice, a load of beans, salad, steak, roast chicken and I would eat. I can serve myself the same amount now, only I won't eat this quantity... But for my eyes, when I see that plate (of food), I have the sensation that I am going to eat all of it."

\section{Final Comments}

According to what is widely reported in the specialized literature, the questions related to the eating impulse in patients with morbid obesity - and their phenomenological expression, hunger - are matters for concern among the team of professionals involved in bariatric surgery.

We observe that the hunger of these patients is transformed, as the ingestion of food is limited, however, the sensation of satiation is not achieved, leading to feelings of anguish, emptiness and weakness, which often end in the patients desperately seeking alternative means to obtain satisfaction.

That which the patients referred to as hunger before the surgery is a complex of physical and emotional sensations. After surgery, these are transformed into vague sensations of emptiness and pain which, through lack of psychic elements that could make an elaboration of the anguish possible, keep the patient imprisoned in a vicious circle of dissatisfaction and pain. In our opinion, from the psychodynamic point of view, this is the etiological substratum of the eating disorders that are so common in the post-operative period, that is, BED, night binging and grazing.

From the results obtained in this study, we believe that it is crucial to provide, besides nutritional advice, psychosocial guidance and clinical and psychiatric care, the possibility of in-depth psychological treatment. The aim of this treatment is to develop psychic areas that did not form during the maturation process. These deficiencies in the constitution of the psyche are responsible for the symptoms, which are the expression of proto-mental areas that function primitively and express themselves in brutal discharges, not mediated by thought. In this sense, measures of guidance, counseling or those that require the patient's to think so as to be carried out are practically useless because they depend on psychic resources that the patient with morbid obesity has yet to develop. In these patients 
we have to deal with representation's emptiness and therefore help them in the task of creating representations and symbols that may help to expand their ability to elaborate the drive demand mentally.

It is important that the bariatric surgeon, when performing the surgery, be aware that he/she is creating a demand for psychological care related to the psychic structure with areas that function primitively, and that were kept in balance by the compulsive ingestion of food. For this reason, health teams should be aware that carrying out a surgical procedure should necessarily be accompanied by an efficient psychotherapeutic process. Thus, our study points to new demands that ensue after a medical act and it attempts to shed light on this emerging field of clinical practice. Further studies that aim to increase knowledge on this matter are essential, and we believe we have shown some new paths for future research.

\section{References}

American Society for Bariatric Surgery. American Society for Bariatric Surgery web site 2007 <www.asbc.org>. Accessed: 2 April 2007.

Atchison, M. et al. Anorexia nervosa following gastric reduction surgery for morbid obesity. Int J Eat Disord, v. 23, p. 111-116, January 1998.

Barros, E. M. da R. Botella, Ogden, Green, Ferro, Bion. Revista Brasileira de Psicanálise, São Paulo, v. 41, p. 33-45, 2007.

Benotti, P. N.; Forse, R. A. The role of gastric surgery in the multidisciplinary management of severe obesity. Am J Surg, v. 169, p. 361-367, 1995.

BION, W. R. Experiências com grupos. Rio de Janeiro: Imago, 1970.

BOCCHIERI, L. E. et al. A review of psychosocial outcomes of surgery for morbid obesity. J Psychosom Res, v. 52, p. 155-165, 2002.

BonNe, O. B. et al. Anorexia Nervosa following gastroplasty in male: two cases. Int $J$ Eat Disorder, v. 19, p. 105-108, January 1996.

Botella, C. Entrevista. Revista Brasileira de Psicanálise, São Paulo, v. 41, p. 19-29, 2007.

Botella, C.; Botella, S. Irrepresentável. Porto Alegre: Criação Humana, 2002.

Buchwald, H. Consensus Conference Statement Bariatric surgery for morbid obesity: health implications for patients, health professionals, and third-party payers. $J \mathrm{Am}$ Coll Surg, n. 200, p. 593-604, 2005.

CoRdÁs, T. A. et al. Transtorno alimentar e cirurgia bariátrica: relato de caso. Arq Bras Endocrinol Metab, v. 48, p. 564-571, 2004. 
Delin, C. R. et al. An exploration of the outcomes of gastric surgery for morbid obesity: Patients characteristics and indices of success. Obes Surgery, v. 5, p. 159170, May 1995.

Denzin, N. K.; Lincoln, Y. S. The SAGE handbook of qualitative research. $3 \mathrm{rd}$ edition. New York: Thousand Oaks Sage Publications, 2005. ; O planejamento da pesquisa qualitativa: teorias e abordagens. 2. ed., Porto Alegre: Artmed, 2006.

Dymeк, M. P. et al. Quality of life and psychosocial adjustment in patients after Rouxen-Y gastric bypass: a brief report. Obes Surg, v. 11, p. 32-39, February 2001.

Fontanella, B. J. B. et al. Coleta de dados na pesquisa clínico-qualitativa: uso de entrevistas não-dirigidas de questões abertas por profissionais da saúde. Revista Latino-americana de Enfermagem, Ribeirão Preto, v. 14, p. 812-820, 2006.

Amostragem por saturação em pesquisas qualitativas em saúde: contribuições teóricas. Caderno de Saúde Pública, Rio de Janeiro, v. 24, p. 17-27, 2008.

Franco FILho, O. de M. Manifestações em psicoterapia analítica de grupo, como funcionamentos mentais primitivos que não evoluíram para representação simbólica. Vínculo, v. 5, p. 16-25, jun. 2008.

Freud, S. (1905). Três ensaios sobre a teoria da sexualidade. In: Edição Standard Brasileira das Obras Psicológicas Completas de Sigmund Freud. 2. ed. Rio de Janeiro: Imago, 1987. v. VII, p. 123-250.

. (1911). Formulações sobre os dois princípios do funcionamento mental. In: Edição Standard Brasileira das Obras Psicológicas Completas de Sigmund Freud. Rio de Janeiro: Imago, 1969. v. XII, p. 273-286.

. (1914). Sobre o narcisismo: uma introdução. In: Edição Standard Brasileira das Obras Psicológicas Completas de Sigmund Freud. 2. ed. Rio de Janeiro: Imago, 1987. v. XIV, p. 85-119.

Glaser, B. G.; Strauss, A. L. The Discovery of Grounded Theory: Strategies for Qualitative Research. New Brunswick: Aldine Transaction, 1999.

GLINSKI, J. et al. The psychology of gastric bypass surgery. Obes Surg, v. 11, p. 581588, October 2001.

HERRMANn, F. Interpretação: a invariância do método nas várias teorias e práticas clínicas. In: Figueira, S. A. Interpretação: sobre o método da psicanálise. Rio de Janeiro: Imago, 1989. p. 13-34.

Hsu, L. K. G. et al. Non-surgical factors that influence the outcome of bariatric surgery: a rewiew. Psychosom Med, v. 60, p. 338-346, 1998.

. Eating disturbances and outcome of gastric bypass surgery: a pilot study. Int J Eat Disorder, v. 21, p. 385-390, 1997.

Rev. Latinoam. Psicopat. Fund., São Paulo, v. 13, n. 3, p. 425-440, setembro 2010 


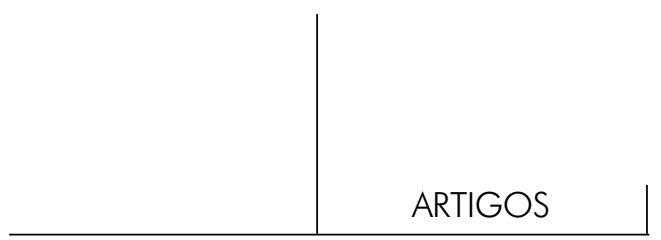

. Eating disturbances before and after vertical banded gastroplasty: a pilot study. Int J Eat Disorder, v. 19, p. 23-34, January 1996.

Kalarchian, M. A. et al. Binge eating among gastric bypass patients at long-term follow-up. Obes Surg, v. 12, p. 270-275, April 2002.

LEVy, R. A visão topográfica no processo psicanalítico: o irrepresentável. Revista Brasileira de Psicanálise, São Paulo, v. 37, p. 1067-1078, 2003.

Magdaleno JR., R. A formação da identidade psicanalítica: a apreensão do método como incorporação de uma ética. Jornal de Psicanálise, São Paulo, v. 38, p. 229-249, 2005.

Magadaleno JR., R et al. Understanding the life experiences of Brazilian women after bariatric surgery. A qualitative study. Obes Surgery, 2009 (in press).

. The psychology of bariatric patient: what replaces obesity? A qualitative research with Brazilian women. Obes Surgery, 2009 (in press).

. Características psicológicas de pacientes submetidos à cirurgia bariátrica.

Revista de Psiquiatria RS, 2009 (in press).

MAGRO, D. O. et al. Long-term weight regain after gastric bypass: a 5-year prospective study. Obes Surg, v. 18, p. 648-651, June 2008.

MalHer, M. (1963). Observações sobre adaptação e defesa "in status nascendi". In: O processo de individuação e separação. Porto Alegre: Artes Médicas, 1982.

Meltzer, D. et al. Metapsicología ampliada - aplicaciones clínicas de las ideas de Bion. Buenos Aires: Spatia, 1990.

Merton, R. K. On Theorical Sociology: Five Essays, Old and New. New York: The Free Press, 1967.

Minayo, M. C. de S. O desafio do conhecimento - pesquisa qualitativa em saúde. 10. ed. São Paulo: Hucitec, 2007.

Morse, J. M.; FIELD, P-A. Qualitative research methods for health professionals. 2. ed.. London: Sage, 1995.

Oliveira, M. T.; Palauro, Y. G. R. Um estudo das questões mentais no quadro clínico da obesidade mórbida. Trabalho apresentado em reunião científica na Sociedade Brasileira de Psicanálise de São Paulo, São Paulo, SP, set.2007.

SANTRY, H. P. et al. Trends in bariatric surgical procedures. JAMA, v. 294, n. 15, p. 1909-1917, October 2005.

SEgAL, A.; FAndiÑo, J. Indicações e contra-indicações para a realização das operações bariátricas. Revista Brasileira de Psiquiatria, São Paulo, v. 24, supl. 3, p. 62-72, dez. 2002.

Rev. Latinoam. Psicopat. Fund., São Paulo, v. 13, n. 3, p. 425-440, setembro 2010 


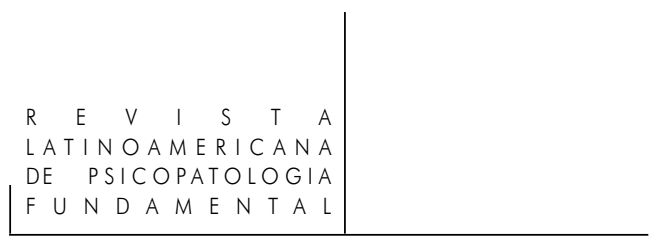

Turato, E. R. Tratado da Metodologia da Pesquisa Clínico-Qualitativa: construção teórico-epistemológica, discussão comparada e aplicação às áreas da saúde e humanas. 3. ed. Petrópolis, RJ: Vozes, 2008.

Tustin, F. Autismo e psicose infantil. Rio de Janeiro: Imago, 1975. . Barreiras autísticas em pacientes neuróticos. Porto Alegre: Artes Médicas, 1990.

VAn Hout, G. C. M. et al. Psychological profile of morbid obese. Obes Surg, v. 14, n. 5, p. 579-588, May 2004.

Weintraub, A. No interior da guerra dos fabricantes de drogas contra a gordura.

Revista Latinoamericana de Psicopatologia Fundamental, São Paulo, v. 11, n. 2, p. 267-277, jun. 2008.

WinnicotT, D. W. (1967). O papel de espelho da mãe e da família no desenvolvimento infantil. In: O brincar e a realidade. Rio de Janeiro: Imago, 1975. p. 153-162.

. (1949). A mente e sua relação com o psicossoma. In: Da pediatria à psicanálise: obras escolhidas. Rio de Janeiro: Imago, 2000. p. 332-346.

WorLD Health Organization. Obesity and overweight. <http://www.who.int/ dietphysicalactivity/publications/facts/obesity/en/> Acesso em: $17 \mathrm{dez} 2008$.

\section{Resumo}

(Tratamento cirúrgico da obesidade: algumas considerações sobre as transformações no impulso alimentar)

Este estudo visa compreender as alterações do impulso alimentar após a cirurgia bariátrica. A fome se transforma após a cirurgia, sendo a saciedade alcançada rapidamente, sem a sensação de satisfação alimentar. Há uma evidente confusão entre a fome enquanto não-saciedade e enquanto insatisfação, sendo a angústia o afeto decorrente e que a cirurgia não corrige. Neste caso, um tratamento psicológico profundo é necessário, já que a cirurgia cria novas demandas emocionais no paciente.

Palavras-chave: Cirurgia bariátrica, obesidade, psicanálise, método qualitativo

(Le traitement chirurgical de l'obésité : considérations sur les trans-formations de l'impulsion alimentaire)

Cette étude vise à comprendre les altérations de l'impulsion alimentaire après la chirurgie bariatrique. Après la chirurgie, la faim se transforme. La satiété est obtenue rapidement mais le sentiment de satisfaction alimentaire ne se produit pas. Il existe une confusion évidente entre la faim comme non satiété, et comme insatisfaction. L'angoisse 


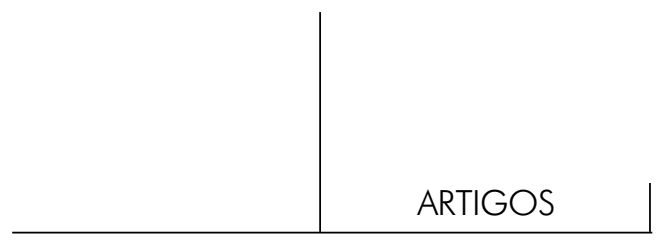

est l'affection que la chirurgie ne peut pas corriger. Un traitement psychologique profond est essentiel, car l'opération crée de nouvelles demandes d'affection pour le patient.

Mots clés: Chirurgie bariatrique, obésité, psychanalyse, méthode qualitatif

(El tratamiento quirúrgico de la obesidad: consideraciones sobre las transformaciones del impulso alimentario)

Este estudio trata de comprender las alteraciones del impulso alimentario derivadas de la cirugía bariátrica. La noción de hambre sufre una transformación, la saciedad es alcanzada rápidamente, pero no ocurre lo mismo con la sensación de satisfacción alimentaria. Hay una evidente confusión entre hambre saciado e insatisfacción, siendo la angustia el afecto resultante que la cirugía no corrige. Es fundamental un tratamiento psicológico profundo pues la cirugía crea nuevas demandas emocionales para el paciente.

Palabras claves: Cirugía bariátrica, obesidad, psicoanálisis, metodo cualitativo

Citação/Citation: Magdaleno Jr., R.; Chaim E.A.; TuRato, E.R. Surgical treatment of obesity: some considerations on the transformations of the eating impulse. Revista Latinoamericana de Psicopatologia Fundamental, São Paulo, v. 13, n. 3, p. 425-440, set. 2010.

Editor do artigo/Editor: Prof. Dr. Manoel Tosta Berlinck

Recebido/Received: 6.7.2009 / 7.6.2009 Aceito/Accepted: 25.9.2009 / 9.25.2009

Copyright: () 2009 Associação Universitária de Pesquisa em Psicopatologia Fundamental/ University Association for Research in Fundamental Psychopathology. Este é um artigo de livre acesso, que permite uso irrestrito, distribuição e reprodução em qualquer meio, desde que o autor e a fonte sejam citados/This is an open-access article, which permits unrestricted use, distribution, and reproduction in any medium, provided the original author and source are credited.

Financiamento/Funding: Os autores declaram não ter sido financiados ou apoiados/The authors have no support or funding to report.

Conflito de interesses/Conflict of interest: Os autores declaram que não há conflito de interesses/The authors declare that has no conflict of interest.

Rev. Latinoam. Psicopat. Fund., São Paulo, v. 13, n. 3, p. 425-440, setembro 2010 


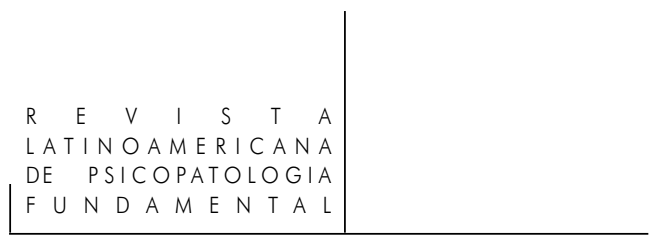

\section{Ronis Magdaleno Júnior}

PhD in Medical Sciences; Psychiatrist; Psychoanalyst; Member of Brazilian Psychoanalytic Society of São Paulo; Member of the Laboratory of Clinical-Qualitative Research; Department of Medical Psychology and Psychiatry; Faculty of Medical Sciences, Universidade Estadual de Campinas - Unicamp (Campinas, SP, Brasil).

Rua Padre Almeida, 515/14

13025-251 Campinas, SP, Brazil

Phone: 55 (19) 3254-2103

e-mail: ronism@uol.com.br

\section{Elinton Adami Chaim}

$\mathrm{PhD}$; Surgeon; Coordinator of Bariatric Surgery Service of General Hospital of Universidade Estadual de Campinas - Unicamp (Campinas, SP, Brasil).

Departamento de Cirurgia da Faculdade de Ciências Médicas da Unicamp

Cidade Universitária Zeferino Vaz

Hospital de Clínicas - Barão Geraldo

13083-970 Campinas, SP, Brazil

Caixa Postal: 6111

Phone: 55 (19) 3521-9450

e-mail: chaim@hc.unicamp.br

\section{Egberto Ribeiro Turato}

Associate Professor of Psychiatry; Coordinator of the Laboratory of Clinical-Qualitative Research; Department of Medical Psychology and Psychiatry; Faculty of Medical Sciences, Universidade Estadual de Campinas - Unicamp (Campinas, SP, Brasil).

Departamento de Psicologia Médica e Psiquiatria da Faculdade de Ciências Médicas da Unicamp

Cidade Universitária Zeferino Vaz - Barão Geraldo

13083-970 Campinas, SP, Brazil

Phone: 55 (19) 3521-9295

e-mail: erturato@uol.com.br 